\title{
INTERSPECIFIC CROSS BETWEEN DURUM WHEAT AND AEGILOPS GENICULATA TO TRANSFER RESISTANCE TO HESSIAN FLY (MAYETIOLA DESTRUCTOR SAY.).
}

\author{
Oum El KHLIFI, Hakima CHAMLAL, Hari SHARMA et Ouafae BENLHABIB
}

\begin{abstract}
Interspecific cross between Durum Wheat and Aegilops geniculata to transfer resistance to Hessian fly (Mayetiola destructor Say.). Interspecific crosses between durum wheat (Triticum durum) and accessions of Aegilops geniculata were initiated the first year of the present program. Only those accessions that were resistant to Hessian fly (Mayetiola destructor Say.) were used with the objective to transfer the resistance to wheat. Embryo rescue of immature hybrid seeds was necessary. Two hybrids between $T$. durum and A. geniculata were produced and planted in the field the second year. They presented intermediate traits between their two parents and produced a progeny after selfing or backcrossing. Meiotic analysis of the pollen mother cells showed low pairing between parental chromosomes in the hybrids.
\end{abstract}

Key words. Triticum durum, Aegilops geniculata, interspecific cross, embryo rescue, mitotic and meiotic analyses.

RÉSUMÉ. Croisement interspécifique entre le blé dur et Aegilops geniculata pour le transfert de la résistance à la mouche de Hesse (Mayetiola destructor Say.) Des croisements interspécifiques entre le blé dur (Triticum durum) et des accessions d'Aegilops geniculata ont été initiés la 1 ère année de ce programme. Seuls les accessions résistantes à la mouche de Hesse (Mayetiola destructor Say.) ont été utilisées dans l'objetif de transférer la résistance au blé. Le sauvetage d'embryons hybrides immatures a été nécessaire. Deux hybrides entre Triticum durum et Aegilops geniculata ont été produits et transférés au champs la $2^{\text {ème }}$ année. Ils ont présenté une morphologie intermédiaire entre leurs deux parents et ont produits une descendance après autofécondation ou rétrocroisement. L'analyse méiotique des cellules mère du pollen a montré un faible appariement entre les chromosomes chez les deux hybrides.

Mots clés. Triticum durum, Aegilops geniculata, interspécifique croisement, sauvetage d'embryons, mitotic et méiotique analyses.

\section{INTRODUCTION}

Wheat yield improvement is dependent upon genetic diversity available in its genetic pool. This diversity has been subjected to high genetic erosion as a result of selection pressure (Porceddu et al., 1988). Thus recourse to the genetic resources available in alien species has become more necessary in recent years (Sharma, 1995). The introduction of alien

This research was supported by PSTC, HCD Bureau of Global Programs, USAID Grant $n^{\circ}$ HRN-5600G-00-2032-00. 
genetic material through interspecific or intergeneric hybridization allowed the transfer of genes for resistance to many diseases and pests (Dvorak, 1977; Jones et al., 1995; Friebe et al., 1996; Valkoun et al., 1990). Even though, this method is confronted with incompatibility barriers that limit hybrid production. Several techniques are available to overcome these barriers, and affect gene introgression into wheat genome (Sears, 1981; Feldman, 1983 ; Baum et al., 1992; Sharma, 1995; MujeebKazi, 1993). A. geniculata is a useful source of variation for wheat improvement, but very much unutilized. Very few hybridizations have been made of this species with durum wheat (Kimber \& Abubaker, 1979; Sharma \& Gill, 1983; Simeone \& Blanco, 1985; Nasyrov \& Ibraginova, 1982; Farooq et al., 1990). In Morocco, durum wheat is grown widely but most cultivars are susceptible to Hessian fly. During some seasons, yield loss can reach up to $80 \%$ (Lhaloui et al., 1992). Therefore, looking for new sources of resistance to this insect in alien species constituted the primary objective in the Moroccan national breeding program. Since then, many resistant accessions were selected in Aegilops species. Our goal is to transfer the Hessian fly resistance genes into Moroccan durum wheat and to explore the alien germplasm of wheat mainly for resistance to Hessian fly.

The objective of this paper is to report the result on the interspecific hybridization over three years and the characterization of hybrids produced between durum wheat and an Aegilops geniculata accession resistant to Hessian fly.

\section{MATERIALS AND METHODS}

Plant material used in this essay included local Moroccan varieties of durum wheat (Oum Rbia, Marzak, Cocorit and Tensift) and $A$. geniculata accessions (400150, 400151, 400159, 400161, 400163). Aegilops accessions were chosen because of their resistance to Hessian fly (El Bouhssini et al., 1997). Field planting of wheat varieties was scheduled at different dates to enhance the chances of nicking with Aegilops. Direct and reciprocal crosses were made manually by spreading pollen on emasculated flowers. Two weeks later, immature hybrid seeds were taken from the mother plants, washed in $70^{\circ}$ alcohol and then surface sterilized in $5 \%$ sodium hypochlorite solution. After a few washes in sterile distilled water, embryos were isolated from the seed and cultured on a modified MS medium (Sharma \& Baenziger, 1986). When developed into plants, hybrids were treated with a solution containing $1 \%$ colchicine and $2 \%$ DMSO, for 5 hours. After two to three weeks acclimatization under controled temperature and humidity, hybrids were planted in the field for their characterization. Plant, spike and leaf traits, fertility and resistance to some common diseases were scored.

Chromosome counts of both parents and hybrids were done on root tips as described by Endo and Gill (1984). Pollen mother cells from hybrids were analyzed for chromosome pairing. For this purpose, spikes were fixed in a $3: 1$ ethanol: acetic acid solution and anthers were squashed in $1 \%$ acetocarmine solution. Fifty

\begin{tabular}{lccccc}
\hline Parents crossed & Male parent & No of florets & \% seed set & \% rescuing & \% plant formed \\
\hline T. durum & A. geniculata & 540 & 3.9 & 42.8 & 1.7 \\
A. geniculata & T. durum & 80 & 6.2 & 40 & 2.5 \\
\hline
\end{tabular}

Table 1: Seed set and hybrid plants produced in T. durum x A. geniculata cross during the first year. 


\begin{tabular}{cccc}
\hline \% Seed set & \% Plant formed & $\begin{array}{c}\text { \% Plant transferred } \\
\text { to field conditions }\end{array}$ \\
\hline Year 1 & 3.9 & 1.7 & 0 \\
Year 2 & 5.0 & 1.8 & 10 \\
Year 3 & 7.3 & 1.8 & 17,7 \\
\hline
\end{tabular}

Table 2. Comparison of hybrid seed set in ( $T$. durum x A. geniculata) cross over three years.

percent of the hybrid spikes were backcrossed to wheat parent and the others were left for selfing.

\section{RESULTS AND DISCUSSION}

Over 500 durum wheat flowers were emasculated and then pollinated with Aegilops geniculata pollen. Average seed set was lower in direct cross with wheat as the female than in the reciprocal one (tab. 1). However, normal embryos were more frequent in direct cross. Of the 15 embryos dissected only one was abnormal, while only 2 out of 5 embryos were normal in reciprocal cross. Maternal effects could be the cause of this difference. Plant regeneration rate was also different in the two crosses, $1.7 \%$ in direct and $2.5 \%$ in reciprocal cross.
Percent seed set between wheat and alien species, including that between tetraploïd wheat and A. geniculata, appears to vary and the differences are not consistent over genotypes, direction of cross, years, locations and research programs (Sharma, 1995). In the present study, seed set was low but within the range reported for this wide cross (Sharma, 1995). It varied from $3.9 \%$ the first year to $7.3 \%$ the third year (tab. 2). Also, up to $17 \%$ of hybrids produced could be transferred successfully to the field during the third year compared to $0 \%$ the first year and $10 \%$ the second year. This improvement in hybrid production was probably due to the addition of a new step for plantlet hardening during the first days following the transfer to the soil. However, the number of hybrids produced was very low and didn't improve from year to year despite our better understanding of the technical

\begin{tabular}{lcccc}
\hline \multicolumn{1}{c}{ Traits } & T. durum parent & A. geniculata parent & H1 hybrid & H2 hybrid \\
\hline Plant height (cm) & 53 & 13 & 50 & 29 \\
Number of spikes & $2-8$ & $63-82$ & 32 & 23 \\
Number of florets & 12 & 2.6 & 7.4 & 3.8 \\
Spike length (cm) & 12.4 & 3.2 & 5.7 & 5.2 \\
Leaf length (cm) & 17.5 & 5.1 & 9.1 & 4.9 \\
Leaf width (cm) & 1.1 & 0.5 & 0.8 & 0.4 \\
Pollen fertility (\%) & 85 & 80 & 25 & 3 \\
Leaf hairiness & light hair & hairy in top leaves & very light hair & no hair \\
Anther dehiscence & + & + & + & - \\
Angled stem & no & yes & yes & yes \\
Resistance to leaf diseases & $\mathrm{S}$ & $\mathrm{R}$ & $\mathrm{R}$ & $\mathrm{R}$ \\
Plant shape & dressed & rosette & dressed & rosette \\
\hline
\end{tabular}

Table 3: Comparison between hybrids and their parents. 


\begin{tabular}{lccccccccc}
\hline Hybrid & No chr & Genome & No. cell & No. I & II rod & II ring & II tot. & No. III & No. IV \\
\hline $\mathrm{H} 1$ & 28 & $\mathrm{ABC}^{\mathrm{u}} \mathrm{M}^{\circ}$ & 52 & 16.84 & 4.86 & 0.32 & 5.18 & 0.17 & 0.019 \\
$\mathrm{H} 2$ & 28 & $\mathrm{ABC}^{\mathrm{u}} \mathrm{M}^{\circ}$ & 28 & 22.90 & 1.5 & 0.06 & 1.56 & 0.65 & 0.00 \\
\hline
\end{tabular}

Table 4: Average chromosome paring in $\mathrm{H} 1$ and $\mathrm{H} 2$ hybrids.

factors that limit interspecific hybridization (tab. 2). Besides the fact that some seeds were without embryos, most hybrids were weak in vitro. After the hybrids were successfully transferred to the pots, they were treated with colchicine but died few days later. Colchicine treatment is one cause that contributed to hybrid loss (Essad \& Cachon, 1965; Lange \& Jochemsen, 1992). Since only $50 \%$ of the plants were treated with colchicine solution the other half was saved.

Two hybrids were transferred to the field the second year; one produced through $T$. durum cv. Cocorit x A. geniculata acc. 400150 (H1) and the other from a reciprocal cross $A$. geniculata acc. $400150 \times$ T. durum cv. Tensift (H2). Hybrid plants and their spikes were intermediate between the two parents (tab. 3). However, plant shape varied and was erect like durum wheat in hybrid $\mathrm{H} 1$ and spreading like A. geniculata in hybrid $\mathrm{H} 2$. Both hybrids inherited some traits from their alien parents such as the resistance to leaf diseases (rust and powdery mildew) and angled straw. However, regarding all the aspects together, $\mathrm{H} 1$ hybrid resembled more to the wheat parent and $\mathrm{H} 2$ to the alien parent. Reciprocal hybrids are generally close in shape to the alien parent. Plant shape, spike morphology, plant height were the traits influenced by maternal effect (tab. 3). Pollen fertility was very low in both hybrids but greater in $\mathrm{H} 2$.
Mitotic analysis showed that chromosome number was equal to that expected: $2 \mathrm{n}=28 ; 14$ chromosomes from wheat parent and the other 14 from Aegilops parent. Meiotic analysis showed that chromosome pairing was relatively low, especially in H2. An average of 5.18 bivalent in the $\mathrm{H} 1$ hybrid and 1.56 in $\mathrm{H} 2$ were observed. Some trivalents and tetravalents were observed but they have low frequency (tab. 4). Univalents were the most frequent reaching 22.9 in $\mathrm{H} 2$ hybrid. In Chinese Spring $\times$ A. geniculata F1 hybrid, Farooq et al. (1990) also noticed low pairing: up to 32.6 univalents were present in each cell. Bailey et al. (1993) obtained the same range (32.7) in H186 bread wheat line $\mathrm{x}$ A. geniculata cross. However, they observed no univalents when they used the ph mutant stock of Chinese Spring wheat in their cross. Low chromosome pairing confirmed differences in chromosome structure between the parental genomes (Rieger et al., 1968). Ph gene in wheat which controls chromosome pairing between homoeologues was probably more active in $\mathrm{H} 2$ hybrid where univalent chromosomes are more frequent. Aegilops geniculata accession used did not inhibit this gene as do some Aegilops species such as A. longissima, A. mutica, A. speltoides (Chueca et al., 1977). The low pairing frequency was also confirmed through the presence of laggard chromosomes at anaphase I (tab. 5). Over 60\% pollen mother cells of the $\mathrm{H} 2$ hybrid showed at

\begin{tabular}{ccccccc}
\hline Nbr laggards & 0 & 1 & 2 & 3 & 4 & 5 \\
\hline H1 $($ T. durum $x$ A. genucalata $)$ & 93.2 & 2.7 & 1.6 & 0.3 & 0.2 & 1.9 \\
H2 A. genucalata $x$ T. durum $)$ & 39.6 & 3.1 & 6.4 & 17.1 & 8.8 & 24.9 \\
\hline
\end{tabular}

Table 5: Percentage of laggard chromosomes in pollen mother cell of hybrids. 


\begin{tabular}{|c|c|c|c|c|}
\hline & $\begin{array}{l}\text { H1 (T. durum } x \\
\text { A. genucalata) } \\
\text { selfed }\end{array}$ & $\begin{array}{l}\text { H1 (T. durum } x \\
\text { A. genucalata) } \\
\text { backcrossed }\end{array}$ & $\begin{array}{c}\mathrm{H} 2(\text { A. genucalata } \\
x T . \text { durum }) \\
\text { selfed }\end{array}$ & $\begin{array}{c}\mathrm{H} 2 \text { (A. genucalata } \\
x \text { T. durum) } \\
\text { backcrossed }\end{array}$ \\
\hline Seed set $(\%)$ & 2.6 & 10 & 0 & 3.3 \\
\hline Embryo rescued & - & 75 & - & 0 \\
\hline $\begin{array}{l}\text { Seed formed withol } \\
\text { rescue }\end{array}$ & out & 38 & - & 0 \\
\hline
\end{tabular}

Table 6: Seed set and germination rate in $\mathrm{H} 1$ and $\mathrm{H} 2$ hybrids.

least one laggard, and $24 \%$ had over 5 chromosomes left behind (tab. 5). In H1, where there were fewer univalents, fewer laggards were observed. These differences in chromosome behavior could be related to the direction of the cross and to the cultivar used as the female parent (Snape et al., 1979).

On selfing and backcrossing, $\mathrm{H} 1$ hybrid produced few seeds, while $\mathrm{H} 2$ hybrid formed seeds only when backcrossed (tab. 6). High sterility observed in both hybrids could be explained by meiotic chromosome abnormalities which were more noticeable in $\mathrm{H} 2$ hybrid than $\mathrm{H} 1$. It could be also linked to a negative nucleo-cytoplasmic interaction as observed by Maan (1983), and Li and Dong (1991) in wheat x Agropyron reciprocal crosses.

Seeds produced on hybrid plants were used in successive generations. Germination rate in $\mathrm{H} 1$ hybrid progeny was better but only in backcross seeds. Young seedlings were planted in the field and were scored for morphological traits. Successive progenies are going to be screened for Hessian fly resistance.

Sterility in hybrids and their progeny confirmed interspecific barrier effect in $T$. durum xA. geniculata cross. Reciprocal crosses that were carried out produced more seeds and plants than direct cross. Phenotypic and cytogenetic variations observed between the two hybrids reflect maternal effect and also chromosome abnormality and less probably somaclonal variation that could have been regenerated in vitro where the hybrids were growing (Chen et al., 1990). Additionally, the variation between the hybrid plants could also be due to heterozygosity in the wild species used or due to rapid genome changes (Sharma et al., 1989). Meiotic analyses showed low chromosome pairing in the hybrids. Gene transfer by recombination will probably be limited because of lack of chromosome pairing due to the difference between the genomes.

\section{RÉFÉRENCES}

BAILEY, K.L., H. HARDING \& D.R. KNOTT 1993- Transfer to bread wheat of resistance to common root rot (Cochliobolus sativus) identified in Triticum timopheevii and Aegilops geniculata. Canad. J. Plant Pathol. 15: 211219.

BAUM, M., E. LAGUDA \& R. APPELS -1992Wide crosses in cereals. Ann. Rev. Pl. Physiol. and Mol. Biol. 43: 117-143.

CHEN, C., J. JAHIER \& Y. CAUDERON -1990Intergeneric hybrids between Triticum aestivum and three crested wheatgrasses: Agropyron mongolicum, Agropyron michnoi, and Agropyron desertorum. Genome 33: 663-667.

CHUECA, M.C., CAUDERONY \& J. TEMPÉ 1977- Technique d'obtention d'hybrides Blé tendre $x$ Aegilops par culture in vitro d'embryons immatures. Ann. Amélior. Plantes 27: 539- 547.

DVORAK, J. -1977- Transfer of leaf rust resistance from Aegilops speltoides to Triticum aestivum. Can. J. Genet. Cytol. 19: 133-141.

EL BOUHSSINI, M., O. BENLHABIB, A. BENTIKA, H.C. SHARMA \& S. LHALOUI 1997- Sources of resistance in Triticum and Aegilops species to Hessian fly (Diptera: Cecidomyiidae) in Morocco. Arab J. Pl. Prot. 
$15(2), 16-128$

ENDO, R. \& B.S. GILL -1984- Somatic karyotype heterochromatic distribution, and nature of chromosome differentiation in common wheat Triticum aestivum L. em. Thell. Chromosoma 81: 361-369.

ESSAD, S. \& H. CACHON -1965- Recherches préliminaires sur orge pour une tentative d'amélioration des traitements par la colchicine. Ann. Amélior. Plantes 15: 5-21.

FAROOQ, S., T.M SHAH \& N. IQBAL -1990Variation in crossability among intergeneric hybrids of wheat and salt tolerant accessions of three Aegilops species. Cereal Research Coтmu. Vol.18, $\mathrm{N}^{\circ}$ 4: 335-338.

FELDMAN, M. - 1983-Gene transfer from wild species into cultivated plants. Genetika 15: 145-161.

FRIEBE, B., J. JIANG, W.J. RAUPP \& R. MCINTOSH -1996- Characterization of wheatalien translocations conferring resistance to diseases and pests: current status. Euphytica 91:59-87.

JONES, S., T. MURRAY \& R. ALLEN -1995- Use of alien genes for disease resistance in wheat. Annu. Rev. Phytopath. 33:429-443.

KIMBER, G. \& M. ABUBAKER -1979- Wheat hybrid information systems. Cereal Res. Commun. 7:257-259.

LANGE, W. \& G. JOCHEMSEN -1992- Use of the gene pools of Triticum turgidum ssp. dicoccoides and Aegilops squarrosa for the breeding of common wheat (T. aestivum), through chromosomedoubled hybrids. II. Morphology and meiosis of the amphiploids. Euphytica 59: 213-220.

LHALOUI, S., L. BUSCHMAN, M. EL BOUHSSINI, A. AMRI, J. HATCHETT, D. KEITH, K. STARKS \& K. EL HOUSSAINI 1992- Infestation of Mayetiola spp. (Diptera: Cecidomyyiidae) in bread wheat, durum wheat and barley: Results of five annual surveys in the major cereal growing regions of Morocco. Al Awamia 77: 21- 52.

LI, H.I. \& Y.S. DONG - 1991 - Hybridization between Triticum aestivum L. and Agropyron michnoi. Roshev. I: Production and cytogenetic study of $\mathrm{F}_{1}$ hybrids. Theo.Appl.Genet 81: 312-316.

MAAN, S.S. -1983- Interspecific hybrid sterility components in Wheat. Proc. 6th International Wheat Genetics Symposium, Kyoto, Japan: 29-37.

MUJEEB-KAZI, A. -1993- Interspecific and intergeneric hybridization in the Triticeae for wheat improvement. In: A.B. Damania (ed.)
Biodiversity and Wheat Improvement. John Wiley \& Sons, pp. 95-102.

NASYROV, S.M. \& G.G. IBRAGINOVA -1982Grain quality in some wheat-Aegilops hybrids. Selektsiya-I-Semenovodstvo, USSR. 11:12-13.

PORCEDDU, E., C. CEOLONI, D. LAFIANDRA, O.A. TANZARELLA \& G.S. MUGNOZZA 1988-Genetic ressources and plant breeding: Problems and prospections. Proc. 7th. Intern. Wheat genet. Symposium, Cambridge, 1: 7-22.

RIEGER, R., A. MICHAELIS \& M.M. GREEN 1968- A glossary of genetics and cytogenetics. Springer-Verlag, N.Y.

SEARS, E.R. -1981- Transfer of alien genetic material to wheat. In: L.T. Evans and W.J. Peacock (Eds.) Wheat Sci. Today and Tomorrow. Cambridge Univ. Press, pp. 75-89.

SHARMA, H.C. - 1995- How wide can a wide cross be? Euphytica 82: 43-64.

SHARMA, H.C. \& P.S. BAENZIGER -1986Production, mophology, and cytogenetic analysis of Elymus caninus (Agropyron caninum) $x$ Triticum aestivum $F_{1}$ hybrids and backcross-1 derivatives. Theor. Appl. Genet. 71: 750-756.

SHARMA, H.C. \& B.S. GILL -1983- Current status of wide hybridization in wheat. Euphytica 32: 17-31.

SHARMA, H., H. OHM, M. LISTER, J. FOSTER \& R. SHUKLE -1989- Response of wheatgrasses and wheat $\mathrm{x}$ wheatgrass hybrids to barley yellow dwarf virus. Theor. Appl. Genet. 77:369-374.

SIMEONE, R. \& A. BLANCO -1985-Morphology, fertility and cytogenetics of the amphiploid Aegilops ovata x Triticum durum Desf. Genetica Agraria 39:348.

SNAPE, J.W., V. CHAPMAN, J. MOSS, C.E. BLANCHARD \& T.E. MILLER - 1979- The crossability of wheat varieties with Hordeum bulbosum. Heredity 42: 291-298.

VALKOUN, J., J. DOSTAL \& D. KUCEROVA 1990- Triticum x Aegilops hybrids through embryo culture. In: Biotechnology in Agriculture and Forestry, Wheat Springer. Verlag, Berlin. Ed. Bajaj Y.P.S. 13: 152-162.

Aceptado para su publicación en septiembre de 2003

Address of the authors. O. EL KHLIFI and H. CHAMLAL: Dept. De Biologie, Faculté des Sciences Ain Chock, Casablanca, Maroc; H. SHARMA: Botany Dept., Purdue University, Indiana, USA; 0. BENLHABIB: Dept. d'Agronomy et d'Ámélioration des Plantes, IAV Hassan II, Rabat, Maroc. 